\title{
FACTORS AFFECTING PREGNANCY RATES AFTER OVUM PICK UP-DERIVED EMBRYO TRANSFER IN LACTATING HOLSTEIN RECIPIENTS UNDER TROPICAL CONDITIONS
}

\author{
Fatores afetando as taxas de gestação após a transferência de embriões derivados de aspiração \\ folicular em receptoras Holstein lactantes sob condições tropicais
}

\author{
Tássia Louregiani Carvalho Pinto ${ }^{1}$, Marina Bottrel Reis Nogueira ${ }^{2}$, José Nélio de Sousa Sales ${ }^{2}$, \\ Rafaela Rodrigues de Carvalho ${ }^{2}$, Robert Andrew Cushman ${ }^{3}$, José Camisão de Souza ${ }^{2}$
}

\begin{abstract}
High milk production, heat, physiological status and management impair reproduction in Holstein cows. The use of in vivo-produced embryos has been reported as an alternative to enhance pregnancy outcome in the tropics; however there are several limitations for its production, especially from variations in superovulatory responses. The in vitro production of embryos would avoid such variations, but few studies have been reported. This study aims to verify the effects of variables related to recipients under a program of routine in vitro embryo transfer on a commercial dairy farm in southeastern Brazil. It was hypothesized that pregnancy rates after transfer of ovum pick up or OPU-derived embryos (ET) to lactating Holstein recipients may be influenced by recipient GnRH-treatment at ET, parity, milk production and body condition score. Recipients (267) were allocated to one of three i.m. treatments given at ET: Control (92) - $2.5 \mathrm{ml}$ saline; Buserelin (86) - $10 \mu \mathrm{g}$ Buserelin acetate; Deslorelin (89) - 750 $\mu \mathrm{g}$ Deslorelin acetate. Ultrasound images and blood samples were taken at ET and seven days later. The first pregnancy diagnosis was performed between 30-40 days and the second between 60-80 days post ET. Data were analyzed by GENMOD (SAS $\left.{ }^{\circledR}\right)$. The proportion of pregnant cows was greater $(\mathrm{P}<0.05)$ in Buserelin-treated recipients $(38.3 \%)$ at the first pregnancy diagnosis than Controls $(24.1 \%)$, but similar to Deslorelin and control cows at the second diagnosis (13.0, 20.9 and 14.6\% in Control, Buserelin and Deslorelin, respectively). In conclusion, Buserelin improved pregnancy rate only transitorily, under the present conditions.
\end{abstract}

Index terms: Bovine; GnRH agonists; progesterone.

\section{RESUMO}

Alta produção leiteira, calor, estado fisiológico e manejo prejudicam a reprodução em vacas Holandesas nos trópicos. A utilização de embriões produzidos in vivo é uma alternativa para melhorar taxas de gestação; no entanto, existem limitações, especialmente pelas variações nas respostas superovulatórias. A produção in vitro de embriões evitaria tais variações, mas poucos estudos estão relatados. O objetivo é verificar os efeitos de variáveis relacionadas às receptoras sob um programa de transferência de embriões (TE) in vitro em fazenda comercial no sudeste do Brasil. Hipotetiza-se que taxas de gestação, após TE de embriões derivados de OPU em receptoras Hosltein em lactação, são influenciadas pelo GnRH aplicado no momento da TE, paridade, produção de leite e escore de condição corporal. As receptoras (267) foram alocadas para um de três tratamentos aplicados no momento da TE: Controle (92) - Salina 2,5 ml; Buserelina (86) - $10 \mu \mathrm{g}$ de buserelina; Deslorelina (89) - $750 \mu \mathrm{g}$ de deslorelina. Ultrassonografia e amostras de sangue realizadas no momento da TE e sete dias depois. O primeiro diagnóstico de gestação foi realizado entre 3040 dias e o segundo entre 60-80 dias pós-TE. Dados foram analisados pelo GENMOD (SAS ${ }^{\circledR}$ ). A proporção de vacas prenhes foi superior $(\mathrm{P}<0,05)$ nas receptoras tratadas com Buserelina $(38,1 \%)$ comparadas com Controle $(24,1 \%)$ no primeiro diagnóstico de gestação, mas semelhante às vacas tratadas com Deslorelina e Controle no segundo diagnóstico (13,0, 20,9 e 14,6\% no Controle, Buserelina and Deslorelina, respectivamente). A Buserelina melhorou a taxa de gestação apenas transitoriamente, nas presentes condições experimentais.

Termos para indexação: Bovino; agonistas de GnRH; progesterona.

\section{INTRODUCTION}

Embryo transfer and GnRH agonists have been used to improve reproductive efficiency in Holstein cows. It is generally accepted that high milk production decreases circulating progesterone concentrations. During gestation, progesterone influences embryo development, stimulates interferon-tau production, and inhibits the luteolytic cascade (Shahneh et al., 2008). Suboptimal progesterone concentrations cause embryo loss and impair gestation.

\footnotetext{
${ }^{1}$ Universidade Federal de Lavras/UFLA - Departamento de Medicina Veterinária/DMV - Cx. P. 3037 - $37200-000$ - Lavras - MG - Brasil tassialcpin@yahoo.com.br

${ }^{2}$ Universidade Federal de Lavras/UFLA - Departamento de Medicina Veterinária/DMV - Lavras - MG - Brasil

${ }^{3}$ U.S. Meat Animal Research Center/USMARC - Clay Center - NE - USA

Received in february 13, 2015 and approved in may 8, 2015
}

Ciênc. Agrotec., Lavras, v. 39, n. 5, p. 498-505, set./out., 2015 
High producing lactating dairy cows tend to have high levels of feed intake and, as a consequence, blood flow through the liver is increased. This, in turn, may increase steroid metabolism and clearance, decreasing circulating progesterone and fertility (Sangsritavong et al., 2002). Decreases in fertility in high producing dairy cows are greater under elevated temperatures (Gacia-Ispierto et al. 2006) and following periods of body condition losses caused by post partum negative energy balance (Carvalho et al., 2014).

Induction of an accessory corpus luteum has been used as a method to elevate circulating progesterone concentrations (Bech-Sabat et al., 2009). Garcia-Ispierto et al. (2006) observed that cows with an additional corpus luteum are 0.32 less likely to lose a pregnancy than cows with a single corpus luteum. Cows receiving GnRH on the day of AI and 12 days later were 3.7 more likely to have an accessory corpus luteum than untreated controls (Lopez-Gatius et al., 2006). Schmitt et al. (1996) reported greater progesterone concentrations associated with the presence of accessory corpora lutea in milk cows injected with $\mathrm{GnRH}$ agonists five days after estrus.

A transitory increase (from 7 to 12 days after estrus) in serum progesterone after a GnRH injection given five days after estrus was reported (Beltran; Vasconcelos, 2008). Similarly, a single GnRH injection administered five days after AI increased serum progesterone eight days later, but without improving pregnancy rates in relation to controls (Howard et al., 2006).

Additionally, most studies utilizing synthetic hormones with the objective of altering luteal function and increasing progesterone concentrations examine the influence on AI or fixed-time AI conception rates. Very few studies are related to the transfer of in vitro-derived embryos to lactating Holstein recipients. The primary aim was to investigate the effect of GnRH agonists at ET on progesterone concentrations, accessory corpora lutea formation, and pregnancy rates in lactating Holstein cows receiving in vitro-produced embryos. A secondary objective was to investigate the possible effects of recipient days in milk, parity, milk production and body condition score on pregnancy outcome.

\section{MATERIAL AND METHODS}

\section{Housing and climate}

The experiment was carried out on a large commercial dairy operation located in Inhauma in the northern region of the State of Minas Gerais - Brazil, between September through December of 2012. The local climate is defined as tropical of altitude, with warm and rainy summers and dry winters. Minimum and maximum average temperatures ranged from $16{ }^{\circ} \mathrm{C}$ to $35^{\circ} \mathrm{C}$ and humidity between $16 \%$ and $62 \%$.

\section{Animals and treatments}

Cows were milked twice a day and managed in free-stall barns. Cows were fed a total mixed diet based on corn silage, soybean meal and corn, formulated to meet or exceed the requirements of lactating dairy cows (National Research Council, 2001). Average days in milk (DIM) and body condition score (BCS) were $190.4 \pm$ 133.0 and $3.37 \pm 0.45$, respectively. In order to analyze the effects of DIM and BCS, two classes were established based on frequency distribution analysis: DIM1 $\leq 130 \mathrm{~d}$ and DIM2 > $130 \mathrm{~d}$; and BCS1 $\leq 3.25$ and BCS2 $>3.25$, respectively. Mean parity and daily milk yield per cow at 14 days post-partum were $2.04 \pm 0.08$ and $26.75 \pm 0.52$ $\mathrm{kg}$, respectively. To evaluate parity and milk yield effects, cows were classified as primiparous and pluriparous, and as average milk producers $(<28.0 \mathrm{~kg} / \mathrm{cow} /$ day $)$ and high producers $(\geq 28.0 \mathrm{~kg} / \mathrm{cow} /$ day $)$. Cows $(\mathrm{n}=267)$ were randomly allocated to one of three treatments given on the same day embryos were transferred. Treatments were applied as a single i.m. injection on the day of embryo transfer: 1) Control ( $\mathrm{n}=92)-2.5 \mathrm{ml}$ saline; 2) Buserelin ( $=86)-10 \mu \mathrm{g}$ Buserelin acetate (Sincroforte ${ }^{\circledR}$, Ouro Fino, Cravinhos, SP, Brazil); 3) Deslorelin $(\mathrm{n}=89)-750 \mu \mathrm{g}$ Deslorelin acetate (Sincrorrelin ${ }^{\circledR}$, Ouro Fino, Cravinhos, SP, Brazil). Cows were checked for estrus twice a day for one hour and assigned to enter treatments and receive embryos seven (6-8) days later. Treatments were applied throughout a four-month period between the months of September and December of 2012, comprising four replicates in which cows diagnosed as open in the first pregnancy check were randomly reassigned to any of the three treatments (Table 1).

\section{Embryos}

Embryos were produced in vitro by a commercial laboratory (Laboratório Querença Embriões- In Vitro ${ }^{\circledR}$, São Paulo, Brazil). After OPU, oocytes were matured, fertilized with semen from Holstein sires of known fertility and cultured for seven days, according to Ruiz Lópes et al. (2013). A group of 30 dry Holstein donors on average (20-40) from the same farm was submitted to weekly OPU sessions. Only excellent or good embryos (Bó; Mapletoft, 2013) were transferred non-surgically to lactating Holstein recipients 6-8 days after natural estrus. 
Table 1: Experimental design demonstrating the number of cows that were sampled at each time point and for each endpoint.

\begin{tabular}{ccccccc}
\hline & Starting cows & $\begin{array}{c}\text { Cows } \\
\text { ultrasounded } \\
\text { for accessory } \\
\text { CL }\end{array}$ & $\begin{array}{c}\text { Cows } \\
\text { ultrasounded } \\
\text { and measured } \\
\text { for P4 }\end{array}$ & $\begin{array}{c}\text { Cows with } \\
\text { accessory CLs }\end{array}$ & $\begin{array}{c}\text { Cows with } \\
\text { accessory } \\
\text { CLs and P4 } \\
\text { measurements }\end{array}$ & $\begin{array}{c}\text { Cows checked } \\
\text { for pregnancy }\end{array}$ \\
\hline Control & 92 & 48 & 23 & 4 & 4 & 92 \\
Buserelin & 86 & 47 & 21 & 24 & 21 & 86 \\
Deslorelin & 89 & 51 & 21 & 12 & 12 & 89 \\
\hline
\end{tabular}

\section{Ovarian ultrasonography evaluation}

For ovarian evaluation, an ultrasound exam (US) was performed using an Aloka SSD 500 unit (Berger, São Paulo, SP, Brazil) and a 5.0 MHz linear transducer. Due to operational and time constraints of the dairy, only subsets (48, 47 and 51 cows from Control, Buserelin and Deslorelin groups, respectively) of cows were US scanned immediately before the embryo transfer and seven days later. Only when a single CL was detected in the first exam cows were assigned to receive an embryo. If more than one CL was detected cows were not included in the experiment. CL and accessory CLs were mapped and their mean diameter measured.

\section{Blood sampling for progesterone (P4) determination}

Immediately before the first ovarian US evaluation and seven days after treatment, $10 \mathrm{ml}$ blood samples were drawn from the coccygeal vein for P4 determination. Samples were immediately cooled and centrifuged within 6 hours $(1000 \times \mathrm{x}, 20$ min). Supernatant plasma was separated, stored in cryo tubes (3810X standard, Eppendorf, Germany) and kept at $-20{ }^{\circ} \mathrm{C}$ until the $\mathrm{P} 4$ assay. Progesterone concentrations were determined in duplicates by a single radioimmunoassay using an RIA kit (Diagnostic Products Corporation, Los Angeles, CA). The intraassay coefficient of variation was $2.03 \%$. A random subset of sixty five cows were sampled for progesterone determination: Control $(\mathrm{n}=23)$ Buserelin $(\mathrm{n}=21)$ and Deslorelin $(n=21)$ due to economic limitations.

\section{Pregnancy diagnosis}

Cows were checked for pregnancy by US at 30-40 days and at 60-80 days post embryo transfer.

For the first and second pregnancy checks 267 events were computed for analyses. Embryo loss was calculated as the number of cows not pregnant at the second check in relation to the number pregnant at the first check.

\section{Statistical analyses}

All statistical analyses were performed using SAS $^{\circledR}$ procedures (SAS, Cary, NC, USA, 2002).

The proportions of pregnant cows, embryo loss and accessory CL presence were treated as generalized model and analyzed using the GENMOD procedure, with the binomial distribution and scaled deviance as options. Mean proportions were compared by preplanned orthogonal contrasts and the probability of $5 \%$ considered significant.

Progesterone concentration data were submitted to the MIXED procedure with the repeated measures option and the first progesterone value as covariate. The model included treatment, day and treatment by day interaction. The error term was cow within treatment. The covariance structure with the largest Akaike value was used. Corpus luteum number and diameter were submitted to analysis of variance using the GLM procedure. The model included treatment, day, and the treatment by day interaction. Means were expressed as least square means and standard error of the mean and compared by the Tukey test at $5 \%$ of significance. To examine the influence of accessory $\mathrm{CL}$ on serum progesterone concentrations, the Day 7 progesterone concentrations were analyzed using the GLM procedure of SAS with accessory CL class (no accessory CL or 1 accessory CL), treatment and CL class by treatment interaction as the fixed effects.

\section{RESULTS AND DISCUSSION}

Pregnancy was not influenced $(\mathrm{P}=0.08)$ by DIM class (20.7 vs. 12.3\%, for DIM1 and DIM2, respectively). Similar pregnancy rates were observed between BCS classes (16.13\%, 25/155 and 16.07\%, 18/112 for BCS1 and BCS2, respectively). Similarly, 
parity did not influence $(\mathrm{P}>0.10)$ pregnancy rates (15.25\%, 18/118 and $16.78 \%, 25 / 149$ for primiparous and multiparous cows, respectively). Recipient days in milk, body condition score and parity were not influential on pregnancy outcomes in this trial. Only a tendency $(\mathrm{P}<0.08)$ was observed in pregnancy for higher DIM (12.3\%) compared to lower DIM $(20.7 \%)$ cows. Higher DIM could cause infertility problems which may have been the case in the present study. The only data relative to parity showed that pregnancy was higher in nulliparous heifers $(34.2 \%)$ than in lactating Holstein recipients (16.3-20.0\%) receiving in vitro produced fresh embryos (Wilson et al., 2005). Another recent study (Carvalho et al., 2014) has clearly identified higher pregnancy rates per artificial insemination (AI) in primiparous compared to multiparous cows (52.7 vs $43.1 \%$ ). These results do not allow a direct comparison with the present study since it is the result of GnRH based synchronization and deals with AI and not embryos. This could suggest that in the present trial pregnancy rate should have been higher in primiparous cows. The lack of pregnancy rate differences between distinct parity class and body condition scores may be the result of adequate management practices in this particular herd. However, overall pregnancy rates were relatively lower (13.04-38.27\%) than those of other studies in Brazil, as reported in a review by Bó et al. (2004), which ranged from 40-50\% and by Galimbert et al. (2001), which observed in zebu-crossbred recipients, pregnancy rates as high as $65 \%$. However, differently from the present study, most embryo recipients in Brazil are non-lactating Holstein-Zebu crossbreds, indicating less vulnerability to the well reported deleterious effects of heat stress (Ferreira et al., 2011) and negative energy balance (Santos; Rutigliano; Sá Filho, 2009; Carvalho et al., 2014) on embryo survival.

Progesterone concentrations were not influenced by the presence of an accessory CL or by its interaction with treatment. On the other hand, Buserelin increased the proportion of cows with an accessory CL $(\mathrm{P}<0.01)$, compared to the Control and Deslorelin groups (Table 2).

There was no effect $(\mathrm{P}=0.98)$ of treatment on the diameter of accessory CLs. The increase in the proportion of cows with accessory CL in the GnRH-treated groups is in agreement with the study of Rajamahendran et al. (1998). Those authors, using Buserelin injections ( $8 \mu \mathrm{g}$, i.m.) and different doses of Deslorelin, as subcutaneous implants $(75,150,700$ e $2100 \mu \mathrm{g})$, placed on the fifth day of the estrous cycle, observed that there was induction of extra ovulation in all cows. A single Buserelin injection $(8 \mu \mathrm{g})$ on the fifth day of the estrous cycle induced ovulation and CL formation in all treated cows (Schmitt et al., 1996). This proportion was approximately twice that reported in this trial for Buserelin (51.06\%). Even lower results $(25.7 \%)$ were reported by Stevenson et al. (2008). These differences may be related to dosage, agonist type, or other conditions not controlled among the trials studied.

Progesterone concentrations were not influenced $(\mathrm{P}=0.84)$ by the treatments and were $4.12 \pm 0.39$, $4.15 \pm 0.42$ and $3.84 \pm 0.41 \mathrm{ng} / \mathrm{ml}$ for Control, Buserelin and Deslorelin treatments, respectively (Table 3). The progesterone concentration in the second sampling day $(5.56 \pm 0.26 \mathrm{ng} / \mathrm{ml})$ was greater $(\mathrm{P}<0.0001)$, compared to that of the first sampling day $(2.51 \pm 0.26 \mathrm{ng} / \mathrm{ml})$.

The goal of increasing progesterone concentrations through the induction of accessory CLs was not reached in the present study. This finding is consistent with that reported by Stevenson et al. (2007), in which, the presence of accessory CLs induced by Gonadorelin 4-9 days after AI, did not change P4 concentrations compared to untreated controls. Similarly, Kaygusuzoglu et al. (2010), using Buserelin $(10.5 \mu \mathrm{g})$ seven days after AI, did not observe changes in $\mathrm{P} 4$ concentrations in pregnant heifers up to 24 days post-AI. However, in other reports there were associations between accessory $\mathrm{CL}$ formation and $\mathrm{P} 4$ concentrations, differing partially from the present results (Rajamahendran et al., 1998; Ullah et al., 1996; Willard et al., 2003). Greater P4 production may be associated with CL hypertrophy and hyperplasia (Shahneh et al., 2008) which could, in part, explain the observations of positive effects on $\mathrm{P} 4$ production, independently of accessory CL presence. Apparently, one of the factors that may have altered the response to the GnRH agonists used was the stage of the follicular wave in which it was injected. Buserelin injections $(10 \mu \mathrm{g}) 11$ days after embryo transfer, or four days later than the day it was given in the present study, increased plasma P4 (Galimberti et al., 2001). This is different from the present results, but those authors did not report whether they used previous values as covariates, which was done in our analyses.

The proportion of pregnant cows was higher $(\mathrm{P}<0.05)$ for the Buserelin treated group compared to controls in the first diagnosis, but did not differ in the second diagnosis (Tables 4 and 5). For the group of cows submitted to both diagnoses embryo losses did not differ $(\mathrm{P}=0.90)$ between treatments, and were $36.84 \%(7 / 19)$, $41.94 \%(13 / 31)$ and $43.48 \%(10 / 23)$ for the Control, Buserelin and Deslorelin groups, respectively. 
Table 2: Proportion of lactating Holstein cows with accessory CLs one week after GnRH agonist treatment or no treatment.

\begin{tabular}{cccc}
\hline \multirow{2}{*}{ Treatment } & \multicolumn{2}{c}{ Accessory CL } & \multirow{2}{*}{ Total } \\
\cline { 2 - 3 } & Absent & Present* & 48 \\
\hline Control & $91.67 \%(44 / 48)$ & $8.33 \%(4 / 48) \mathrm{c}$ & 47 \\
Buserelin & $48.94 \%(23 / 47)$ & $51.06 \%(24 / 47) \mathrm{a}$ & 51 \\
Deslorelin & $76.47 \%(39 / 51)$ & $23.53 \%(12 / 51) \mathrm{b}$ & 146 \\
Total & $72.60 \%(106 / 146)$ & $27.40 \%(40 / 146)$ & \\
\hline
\end{tabular}

*Different letters within the column indicate statistical difference $(\mathrm{P}<0.05)$.

Table 3: Progesterone concentrations in Holstein cows on embryo transfer day (GnRH-agonist treatment) and seven days later. Numbers are least square means (LSM) \pm standard error of the means.

\begin{tabular}{|c|c|c|c|c|c|}
\hline \multirow{3}{*}{$\operatorname{Trt}^{\mathrm{a}}$} & \multicolumn{2}{|c|}{ Progesterone $(\mathrm{ng} / \mathrm{ml})$} & \multirow{2}{*}{\multicolumn{3}{|c|}{ Probability }} \\
\hline & \multicolumn{2}{|c|}{ Day $^{\mathrm{b}}$} & & & \\
\hline & 7 & 14 & Trt & Day & Trt*Day \\
\hline Con $(n=23)$ & $2.56 \pm 0.42$ & $5.68 \pm 0.43$ & 0.84 & 0.0001 & 0.17 \\
\hline Bus $(n=21)$ & $2.39 \pm 0.45$ & $5.91 \pm 0.46$ & & & \\
\hline $\operatorname{Desl}(\mathrm{n}=21)$ & $2.58 \pm 0.45$ & $5.10 \pm 0.46$ & & & \\
\hline
\end{tabular}

${ }^{a}$ Trt = Treatment; Con (Control); Bus (Buserelin); Desl (Deslorelin). ${ }^{b}$ Day 7 (day of embryo transfer); Day 14 (seven days after embryo transfer).

Table 4: Pregnancy at the first diagnosis (30-40 days after transfer) in GnRH agonist-treated and untreated lactating Holstein recipients after OPU-derived embryo transfer.

\begin{tabular}{cllc}
\hline Treatment & \multicolumn{1}{c}{ Pregnant } & \multicolumn{1}{c}{ Open } & Total \\
\hline Control & $24.05 \%(19 / 92) \mathrm{b}$ & $75.95 \%(60 / 92)$ & 92 \\
Buserelin & $38.27 \%(31 / 86) \mathrm{a}$ & $61.73 \%(50 / 86)$ & 86 \\
Deslorelin & $28.05 \%(23 / 89) \mathrm{ab}$ & $71.95 \%(59 / 89)$ & 89 \\
Total & $30.17 \%(73 / 267)$ & $69.83 \%(169 / 267)$ & 267 \\
\hline
\end{tabular}

Different superscripts indicate statistical differences at $\mathrm{P}=0.02$.

Table 5: Pregnancy at the second diagnosis (60-80 days after transfer) in GnRH agonist-treated and untreated lactating Holstein recipients after OPU-derived embryo transfer.

\begin{tabular}{cccc}
\hline Treatment & Pregnant & Open & Total \\
\hline Control & $13.04 \%(12 / 92)$ & $86.96 \%(80 / 92)$ & 92 \\
Buserelin & $20.93 \%(18 / 86)$ & $79.07 \%(68 / 86)$ & 86 \\
Deslorelin & $14.61 \%(13 / 89)$ & $85.39 \%(76 / 89)$ & 89 \\
Total & $16.10 \%(43 / 267)$ & $83.90 \%(224 / 267)$ & 267 \\
\hline
\end{tabular}

$\mathrm{P}=0.32$.

Ciênc. Agrotec., Lavras, v. 39, n. 5, p. 498-505, set./out., 2015 
Most pregnancy rate data found in the literature examining $\mathrm{GnRH}$ agonist use relates to AI or fresh embryo transfer outcomes and few with in vitro-produced embryos. Considering only the first group of cows diagnosed at 30-40 days, Buserelin increased the proportion pregnant compared to controls. Similarly, although relative to AI and injection at estrus, Kaim et al. (2003) reported a 14.2\% increase in pregnancy rate favoring the use of Buserelin, whereas for Gonadorelin-treated lactating cows five days post AI (Howard et al., 2006), a pregnancy rate of $26.7 \%$ was lower than that of the present trial for Buserelin $(38.3 \%)$.

For the group of cows diagnosed at 60-80 days there was no effect of treatment on pregnancy rates. Similarly, the pregnancy rate at 55 days post-AI was not increased by GnRH given on 5 and 15 days after AI (Bartolome et al., 2005). Similar results were reported by Galimberti et al. (2001), when no pregnancy rate differences were found between cows treated with Buserelin four days after ET (65.0\%) and untreated controls (63.6\%). Those pregnancy rates are greater than the ones reported in this trial, and may reflect higher viability of in vivo-produced embryos and, likely, the better adaptation of Zebu-Holstein crossbred recipients to the Brazilian tropical environment than Holsteins. On the other hand, Marques et al. (2012) reported that $10 \mu \mathrm{g}$ of Buserelin given on day 7 of the estrous cycle increased pregnancy rates on crossbred recipients that received frozen-thawed embryos produced in vivo. In agreement with the present findings, Khoramian et al. (2011) reported similar pregnancy rates to AI between cows treated with $20 \mu \mathrm{g}$ of Buserelin, 5-6 days after AI, and untreated controls.

Cows treated with GnRH 14 days after ovulation (Franco et al., 2006) showed significant improvement in pregnancy rates compared to controls (20.3\% vs. $12.7 \%)$. In the present experiment, the proportions of pregnant cows treated with Buserelin and controls were $20.9 \%$ and $13.0 \%$, respectively. Lopez-Gatius et al. (2006) injected Gonadorelin at AI (GnRH-0), or GnRH at AI and 12 days later $(\mathrm{GnRH}-0+12)$, or did not treat (control) lactating Holstein cows. Those authors observed 0.46 and 0.80 decreases in the risk of pregnancy in the control and the GnRH-0 groups, respectively, compared to the GnRH+12 group. The two GnRH injections may have minimized the infertility problems associated with heat stress, since the summer conception rate was $35 \%$ for these cows compared to $34 \%$ in the winter. Considering that the present experiment was conducted in an equally hot climate, no improvement was achieved with a single injection; it could be argued that perhaps a second injection could have been beneficial, similarly to their findings. Again, caution should be exerted in such comparison, for, in the present study, in vitro-derived embryos were transferred as opposed to artificial insemination. Contrarily, in part, to the present observations, Shahneh et al. (2008) reported pregnancy rate improvements for GnRH-treated cows at AI, since $55 \%$ of these cows became pregnant compared to only $25 \%$ in the untreated controls.

The transitory improvement in pregnancy rate for the Deslorelin treatment could not be associated with greater progesterone concentrations in this study. Similarly, in one report (Chagas; Lopes; Robalo, 2002) progesterone concentrations at the time of ET were not different between recipients that became pregnant compared to those that did not. Perhaps, a putative direct effect of GnRH on early pregnancy maintenanceassociated factors, such as vascular endothelial growth factor (Echternkamp et al. 2006; Farin; Piedrahita; Farin, 2006), not measured in this study, could be postulated. In fact, the percentage drop in pregnancy between the first and the second diagnoses was $17.3 \%$ for the Buserelin group compared to 11.0 and $13.4 \%$ in the Control and Deslorelin groups, respectively. Perhaps in the case of an accessory CL there are greater concentrations of $\mathrm{P} 4$ at the level of the gravid uterus due to counter-current transfer than what would be measured in the peripheral blood, because this was the only noticeable difference between the Buserelin group and the remaining treatments. In addition, even a deleterious effect of excessive progesterone between 30 and 60 days of gestation could be considered. This observation poses yet, a more complex probability for a chain of physiological events, following the use of Buserelin, not foreseeable in our current experimental design.

\section{CONCLUSIONS}

A single injection of Buserelin given seven days after estrus improved 30 to 40 -day pregnancy rates in lactating Holstein which receiving OPU-derived embryos. A greater proportion of Buserelin treated cows formed accessory CLs, but it did not have a reflex on peripheral progesterone concentrations. Alternative mechanisms may be involved in pregnancy maintenance during its early stages. This improvement, however, was not seen at the 60-80 day pregnancy rate, leading to the conclusion that more studies are necessary to elucidate GnRH action mechanisms. This study shows that in warm climates it may be feasible to incorporate the use of in vitro-derived embryos in the routine reproductive management of large 
dairy operations to improve fertility. Further studies are warranted, since the pregnancy establishment requirements for OPU-derived embryos may differ in unknown aspects when compared to embryos produced in vivo.

\section{ACKNOWLEDGEMENTS}

The authors would like to thank Laboratório Ouro Fino, Fazenda São João and Rehagro for their contribution.

\section{REFERENCES}

BARTOLOME, J. A. et al. Strategic use of gonadotrophinreleasing hormone $(\mathrm{GnRH})$ to increase pregnancy rate and reduce pregnancy loss in lactating dairy cows subjected to synchronization of ovulation and timed insemination. Theriogenology. 63(4):1026-1037, 2005.

BECH-SABAT, G. et al. Pregnancy patterns during the early fetal period in high producing dairy cows treated with $\mathrm{GnRH}$ or progesterone. Theriogenology. 71(6):920-929, 2009.

BELTRAN, M. P.; VASCONCELOS, J. L. M. Conception rate in Holstein cows treated with GnRH or hCG on the fifth day post artificial insemination during summer. Brazilian Journal of Veterinary and Animal Sciences. 60(3):580-586, 2008.

BÓ, G.A. et al. Manipulação hormonal do ciclo estral em doadoras e receptoras de embrião bovino. Acta Scientiae Veterinariae. 32:1-22, 2004.

BÓ, G. A.; MAPLETOFT, R. J. Evaluation and classification of bovine embryos. Animal Reproduction. 10(3):344-348, 2013.

CHAGAS, S, J.; LOPES C, L, da.; ROBALO S, J. Plasma progesterone profiles and factors affecting embryo-fetal mortality following embryo transfer in dairy cattle. Theriogenology. 58:51-59, 2002.

CARVALHO, P.D. et al. Relationships between fertility and postpartum changes in body condition and body weight in lactating dairy cows. Journal of Dairy Science. 97(6):3666-3683, 2014.

ECHTERNKAMP, S.E. et al. Increased vascular endothelial growth factor and pregnancy-associated glycoproteins, but not insulin-like growth factor-I, in maternal blood of cows gestating twin fetuses. Journal of Animal Science. 84:2057-2064, 2006.
FARIN, P.W.; PIEDRAHITA, J.A.; FARIN, C.E. Errors in development of fetuses and placentas from in vitroproduced bovine embryos. Theriogenology. 65:178191, 2006.

FERREIRA, R. M. et al. The low fertility of repeatbreeder cows during summer heat stress is related to a low oocyte competence to develop into blastocysts. Journal of Dairy Science. 94:2383-2392, 2011.

FRANCO, M. et al. Effectiveness of administration of gonadotropin-releasing hormone at days 11,14 or 15 after anticipated ovulation for increasing fertility of lactating dairy cows and non-lactating heifers. Theriogenology. 66(4):945-954, 2006.

GALIMBERTI, A. M. et al. Pregnancy rate and plasma progesterone concentrations in bovine embryo recipients treated with buserelin after embryo transfer. Brazilian Journal of Animal Science. 30(2):353-359, 2001.

GARCIA-ISPIERTO, I. et al. Relationship between heat stress during the peri-implantation period and early fetal loss in dairy cattle. Theriogenology. 65(4):799-807, 2006.

HOWARD, J. M. et al. Conception rates and serum progesterone concentration in dairy cattle administered gonadotropin releasing hormone 5 days after artificial insemination. Animal Reproduction Science. 95(34):224-233, 2006.

KAIM, M. et al. Effects of GnRH administered to cows at the onset of estrus on timing of ovulation, endocrine responses, and conception. Journal of Dairy Science. 86(6):2012-2021, 2003.

KAYGUSUZOGLU, E. et al. Effect of GnRH administered 7 days after insemination on serum progesterone, luteinizing hormone and duration estrous cycle with pregnancy rates in Heifers. Journal of Animal and Veterinary Advances. 9(9):1400-1405, 2010.

KHORAMIAN, B. et al. Comparison of the effects of gonadotropin-releasing hormone, human chorionic gonadotropin or progesterone on pregnancy per artificial insemination in repeat-breeder dairy cows. Research in Veterinary Science. 90(2):312-315, 2011. 
LOPEZ-GATIUS, F. et al. The effects of GnRH treatment at the time of $\mathrm{AI}$ and 12 days later on reproductive performance of high producing dairy cows during the warm season in northeastern Spain. Theriogenology. 65(4):820-830, 2006.

MARQUES, M. et al. Follicular dynamics and pregnancy rates in Bos taurus $\mathrm{x}$ Bos indicus embryo transfer recipients treated to increase plasma progesterone concentrations. Animal Reproduction. 9(2):111-119, 2012.

NATIONAL RESEARCH COUNCIL. Nutrient Requirements of Dairy Cattle. $7^{\text {th }}$ rev. ed. Washington, DC. National Academy of Science, 2001. 381p.

RAJAMAHENDRAN, R. et al. Effects of Buserelin injection and Deslorelin (GnRH-agonist) implants on plasma progesterone, $\mathrm{LH}$, accessory $\mathrm{CL}$ formation, follicle and corpus luteum dynamics in Holstein cows. Theriogenology. 50(7):1141-1155, 1998.

RUIZ LÓPEZ, S. et al. Use of sex-sorted and unsorted frozen/thawed sperm and in vitro fertilization events in bovine oocytes derived from ultrasound-guided aspiration.

Revista Brasileira de Zootecnia. 42(10):721-727, 2013.

SANGSRITAVONG, S. et al. High feed intake increases liver blood flow and metabolism of progesterone and estradiol-17 beta in dairy cattle. Journal of Dairy Science. 85(11):2831-2842, 2002.

SANTOS, J.E.P.; RUTIGLIANO, H.M.; SÁ FILHO, M.F. Risk factors for resumption of postpartum estrous cycles and embryonic survival in lactating dairy cows.

Animal Reproduction Science. 110(3-4):207-221, 2009.

SAS. A Handbook of Statistical Analyses using SAS.

2 ed. Boca Raton; London; New York; Washington, D.C., 2002. 351p.
SCHMITT, E. J. P. et al. A cellular and endocrine characterization of the original and induced corpus luteum after administration of a gonadotropin-releasing hormone agonist or human chorionic gonadotropin on day five of the estrous cycle. Journal of Animal Science. 74(8):1915-1929, 1996.

SHAHNEH, A. Z. et al. The Effect of GnRH injection on plasma progesterone concentrations, conception rate and ovulation rate in Iranian Holstein cows. Journal of Animal and Veterinary Advances. 7(9):1137-1141, 2008.

STEVENSON, J. S. et al. Interventions after artificial insemination: Conception rates, pregnancy survival, and ovarian responses to gonadotropin-releasing hormone, human chorionic gonadotropin, and progesterone. Journal of Dairy Science. 90(1):331340, 2007.

STEVENSON, J. S. et al. Maintenance of pregnancy in dairy cattle after treatment with human chorionic gonadotropin or gonadotropin-releasing hormone.

Journal of Dairy Science. 91(8):3092-3101, 2008.

ULLAH, G. et al. Effect of gonadotropin-releasing hormone at estrus on subsequent luteal function and fertility in lactating Holsteins during heat stress.

Journal of Dairy Science. 79(11):1950-1953, 1996.

WILLARD, S. et al. The effects of GnRH administration postinsemination on serum concentrations of progesterone and pregnancy rates in dairy cattle exposed to mild summer heat stress. Theriogenology. 59(8):1799-1810, 2003.

WILSON, R.D. et al. In vitro production of Holstein embryos using sex-sorted sperm and oocytes from selected cull cows. Journal of Dairy Science. 88:776782, 2005. 